\title{
A structural approach in the study of bones: fossil and burnt bones at nanosize
} scale

\author{
Giampaolo Piga ${ }^{1 *}$, Maria Dolors Baró ${ }^{2}$, Irati Golvano Escobal ${ }^{2}$, David Gonçalves ${ }^{3,4,5}$, Calil \\ Makhoul $^{5}$, Ana Amarante ${ }^{6}$, Assumpció Malgosa ${ }^{7}$, Stefano Enzo $^{8}$, Sebastiano Garroni ${ }^{8}$ \\ * corresponding author: Dr. Giampaolo Piga, giapiga@ uniss.it, +393407840935
}

${ }^{1}$ POLCOMING-Department of Political Science, Communication, Engineering and Information Technologies, University of Sassari. Viale Mancini 5, I-07100 Sassari (Italy).

${ }^{2}$ Departament de Física, Universitat Autònoma de Barcelona (UAB), E-01893 Bellaterra (Spain).

${ }^{3}$ Research Centre for Anthropology and Health, Department of Life Sciences, University of Coimbra. Calçada Martim Freitas, 3000-456, Coimbra (Portugal).

${ }^{4}$ Archaeosciences Laboratory, Directorate General for Cultural Heritage and LARC/CIBIO/InBIO, Rua da Bica do Marquês 2, 1300-087 Lisboa (Portugal).

${ }^{5}$ Centre for Functional Ecology, Department of Life Sciences, University of Coimbra, Calçada Martim Freitas, 3000-456, Coimbra (Portugal).

${ }^{6}$ Department of Life Sciences, Faculty of Sciences and Technology of the University of Coimbra, Calçada Martim Freitas, 3000-456, Coimbra (Portugal).

${ }^{7}$ GROB (Grup de Recerca en OsteoBiografia), Unitat d'Antropologia Biològica, Dept. BABVE, Facultat de Biociències, Universitat Autònoma de Barcelona, E-01893 Bellaterra (Spain).

${ }^{8}$ Department of Chemistry and Pharmacy, University of Sassari. Via Vienna 2, I-07100 Sassari (Italy).

\begin{abstract}
We review the different factors affecting significantly mineral structure and composition of bones. Particularly, it is assessed that micro-nano-structural and chemical properties of skeleton bones change drastically during burning; the micro- and nano-structural changes attending those phases manifest themselves, amongst others, in observable alterations to the bones colour, morphology, microstructure, mechanical strength and crystallinity.

Intense changes involving the structure and chemical composition of bones also occur during the fossilization process. Bioapatite material is contaminated by an heavy fluorination process which, on a long-time scale reduces sensibly the volume of the original unit cell, mainly the a-axis of the
\end{abstract}


hexagonal P63/m space group. Moreover, the bioapatite suffers to a varying degree of extent by phase contamination from the nearby environment, to the point that rarely a fluorapatite single phase may be found in fossil bones here examined.

TEM images supply precise and localized information, on apatite crystal shape and dimension, and on different processes that occur during thermal processes or fossilization of ancient bone. complementary to that given by X-ray Diffraction and Attenuated Total Reflection Infrared spectroscopy. We are presenting a synthesis of XRD, ATR-IR and TEM results on the nanostructure of various modern, burned and palaeontological bones.

\section{INTRODUCTION}

Bones and teeth are often the only direct remains of animals and humans and hence represent valuable archives that are able to give stratigraphic, paleontological and archaeological data [1-5]. In fact minerals in fossil bones can have specific alteration in appropriate circumstances, which qualify it for determination of its chronology, paleo-environment and sometimes paleo-climate [67]. Considering multiple uses and importance of bone studies, a well-known bone structure is expected.

Bone has a hierarchical structure composed of different structural units at different size scales [8]. These units work in concert to perform different functions and especially to impart good mechanical properties to the bone [9-11]. The material is constituted by both organic (largely collagen, $\sim 30$ wt\%) and inorganic (largely calcium phosphate) components. Microscopically, the mineral phase, which accounts for 60-70 weight \% [12] can be referred to as an impure, non-stoichiometric and poorly crystalline form of hydroxylapatite (HA), with a basic nanosized bioapatite structure of $\mathrm{Ca}_{10}\left(\mathrm{PO}_{4}\right) 6(\mathrm{OH})_{2}$ embedded in an organic matrix. This mineral phase may identify with dahllite, similar to hydroxyapatite but containing up to $7 \mathrm{wt} \%$ of carbonate [13-17, 12].

However, whereas hydroxylapatite has a Ca:P molar ratio of 5:3 (1.67), bone mineral itself has Ca:P ratios ranging from 1.37-1.87 [18]. This is because the composition of bone mineral is much more complex and contains additional ions such as strontium, magnesium, zinc and sodium substituting for calcium, and carbonate groups substituting for phosphate $\mathrm{PO}_{4}{ }^{3-}$ groups [19].

The natural bioapatite crystal may be envisaged as an ordered arrangement of such unit cell repeated periodically along the three orthogonal spatial directions. Biological apatites of bones are made by tiny microcrystals of bioapatite that have been shown to be of needle-like shape having characteristic size length from $50-60 \AA$ up to $150-180 \AA\left(1 \AA=10^{-8} \mathrm{~cm}\right)[20-21]$. 
A number of different factors can alter structure and composition of the bioapatite mineral. One of the more important changes to the microstructure of bone occurs during heating process. Although still not fully understood, current research suggests that as burning intensity increases so does the extent of crystal change. This is exhibited as increasing crystal size, increasing crystalline organisation, and decreasing crystal strain within the bone. In addition to this, severe changes involving the structure and chemical composition of bones may also occur during the fossilization process.[2-3].

The knowledge of the spatial arrangement of atoms and molecule inside the unit cell and the fraction composition of different phases present in the polycrystalline compound under investigation, are complemented with the possibility to determine the microstructural information, such as dimension, orientation of crystallites and lattice disorder. The determination of these details enables to hypothesise and design possible properties of such analysed material.

With all this in mind, it has been argued that a better and more reliable means of addressing the microstructural study of burned and fossil bones is the X-ray diffraction (XRD) approach, possibly combined with other types of physico-chemical and spectroscopic approaches such as ATR-IR and Transmission electron microscopy (TEM) [22]. TEM is a very appropriate technique to reveal peculiar recrystallization phenomena, and is totally complementary to XRD and ATR-IR. Nevertheless, only few applications of combined XRD/ATR-IR/TEM have been performed on archaeological and palaeontological bone [23-24].

The goal of this investigation is to enlighten the potential of TEM to give precise and localized information, complementary to that given by XRD, on bioapatite crystal shape and dimension, and on different processes that occur during thermal processes or fossilization of ancient bones collection of XRD, ATR-IR and TEM results on the macro- to the nanostructure of various modern, burned and palaeontological bones is here presented and discussed.

\section{MATERIAL AND METHODS}

\section{a) Sampling}

For this study we analyzed 16 bone fragments (see Table 1) which were selected to cover a wide age range from present times back to Middle Triassic (245 Ma). The set of samples includes seven fossil bones (IPS-35594, Patiras, MB10-114, TB-3, Orcau-1, Espinau, IPS-37438), one ancient human bone (UF-755), four burned human bones (T252, C5T9, CCNII8-VII (1100), D-1100) and four recent human bones (CCNI17-VI, CCNI18-VI, CCNII8-VII, CEIXXI160). 
Particularly the UF-755 sample is a benign cartilaginous tumor (called: enchondroma), located in the medullary cavity of the femur and it dates back to Carolingian age (VIII ${ }^{\text {th }}-\mathrm{X}$ century BC). The T252 and C5T9 burned bone originate from the Necropolis of Monte Sirai (Carbonia, Sardina, Italy) and Aguilar de Montuenga (Soria, Spain).

Fossil, ancient and burnt bone specimens were selected from a collections stored at Institut Català de Paleontologia (Sabadell-Barcelona, Spain) and the Universitat Autonoma de Barcelona (Spain). The modern samples are part of the $21^{\text {st }}$ century collection of identified human skeletons of the Laboratory of Forensic Anthropology of the University of Coimbra (Portugal) [25].

This collection is composed of unclaimed skeletons from the Capuchos cemetery (Santarém) that have been donated for scientific research. The first skeleton (CEIXXI 160) is from an individual whose sex and age at death is known (Male; 87 years old). The remaining two skeletons (CCNII7 and $C C N I 18$ ) are from unidentified individuals who were nonetheless estimated to be adult females based on anthropological examinations.

\section{b) Physical Techniques}

A small fraction $(0.5 \mathrm{~g})$ of each sample was ball milled in a jar with 2 balls (both made of agate) for one-minute using a SPEX mixer-mill model 8000. $190 \mathrm{mg}$ of powdered bones have been deposited in a dedicated sample holder for XRD analysis with a circular cavity of $25 \mathrm{~mm}$ in diameter and 2 $\mathrm{mm}$ in depth. The XRD patterns were collected using Bruker D2-Phaser instrument working at a power of $30 \mathrm{Kv}$ and $10 \mathrm{Ma}$ in the Bragg-Brentano vertical alignment with a $\mathrm{Cu}-\mathrm{Ka}$ tube emission $(\lambda=1.5418 \AA)$. The width of divergent and antiscatter slits was $1 \mathrm{~mm}\left(0.61^{\circ}\right)$. Primary and secondary axial Soller slits of $2.5^{\circ}$ were also mounted with a linear detector LYNXEYE with $5^{\circ}$ opening and a monochromatisation by $\mathrm{Ni}$ foil for the $\mathrm{K}_{\beta}$ radiation. The powder patterns were collected in the angular range $9^{\circ}-140^{\circ}$ in $2 \theta$ with a step size of $0.05^{\circ}$. The collection time of each pattern was pursued for $47 \mathrm{~min}$.

Digitized diagrams were initially subjected to a pre-processing for qualitative phase recognition according to the programs Highscore ${ }^{\circledR}$ and Match $^{\circledR}$ and then analyzed quantitatively according to the Rietveld method [26], using the programme MAUD [27]. It is worth noting that one stringent requirement of any Rietveld program need the correct loading of the crystal structure solution of substances not only concerning space group and lattice parameters but including also atomic location of asymmetric unit [28]. 
MAUD program is able to represent in a 3D space the shape of cristallites on account of anisotropic effects retrived from the $h k l$ broadening following the Popa model [29]. In this work we used such representation just for the Bioapatite phase, even in case of multiphase specimens.

Morphological and microstructure properties of the bone fragments were characterized by transmission electron microscopy (TEM) on a Jeol-JEM 2011 microscope operated at $200 \mathrm{Kv}$. Samples for TEM observation were prepared by dispersing a small amount of powder in ethanol and then two drops of the suspension were deposited onto a holey carbon supported grid. Elaboration of imagines (particle sizes analysis) has been performed by the Gatan ${ }^{\circledR}$ software.

FT-IR spectra were collected in ATR mode with a Bruker Alpha Platinum-ATR interferometer in terms of absorbance vs wavenumber $v$ in the range $370-4000 \mathrm{~cm}^{-1}$, with a resolution of $4 \mathrm{~cm}^{-1}$. Each spectrum was obtained by averaging 1024 interferograms. The loose powder was dispersed inside a hole cavity of spheroidal shape with its surface aligned to the plate defining it.

The Crystallinity Index (called also Splitting factor SF) adopted here is the same as has been used in the majority of archaeological applications [30-38]. The absorption bands at 6.050 and $5.650 \mathrm{~mm}^{-1}$ were used following baseline correction, and the heights of these absorptions peaks were summed and then divided by the height of the minimum value between both peaks [30].

Two of bone samples (D-1100 and CCNII8-VII) were burned experimentally in a muffle furnace.

The experimental burnings were carried out in an electric muffle (Barracha K-3, three-phased 14A model). The bones were all subjected to gradually increasing heating from room temperature to $1100^{\circ} \mathrm{C}$, with a heating rate of $5^{\circ} \mathrm{C} / \mathrm{min}$, followed by a cooling step up to room temperature.

\section{RESULTS AND DISCUSSION}

Table 2 shows the results obtained from XRD e ATR-IR techniques concerning the bone specimens here investigated. For the natural bioapatite used to describe the XRD powder patterns, it is customary to make use of the hexagonal structure with space group P63/m, even if in some cases a monoclinic structure $\mathrm{P} 21 / \mathrm{c}$ may reveal more flexible in order the model closely follows the experimental data points [39]. Regarding the identified mineral phases we must make a distinction between fossil and modern/burned bones. The fossil bones often present a complex set of different phases due to a long and strict process of fossilization lasted millions of years. The amount of bioapatite may be drastically reduced, due to the replacement of other minerals of the sediment in the bone structure (for example the IPS-35594 and IPS-37438 samples, where bioapatite is reduced to 53 wt.\% and 51 wt.\% respectively). Cases worth of note are represented by Patiras dinosaur, 
which turned out to be 100 wt.\% of bioapatite phase according to XRD, and MB10-114 dinosaur tooth (97 wt.\% of bioapatite).

Regarding the burned and modern bones, in the majority of cases we have a composition of 100 wt.\% of bioapatite, except some archaeological samples (including the UF-755 tumor sample), which present quartz or calcite of likely exogenous origin. Exceptions are the D-1100 sample, which has developed $\beta$-TCP due to the heat treatment. Moreover, the sample CCNII7-VI, which presents $10 \mathrm{wt} . \%$ of brushite will be discussed below.

The unit cell volume of the examined bioapatite varies from a lower value of $521.8 \AA^{3}$ (Patiras) to an upper figure of $524.6 \AA^{3}$ (IPS-35594).

This range of values can be attributed to fluorapatite-like or francolite-like phases. In facts, the literature data referred to fluorapatite supply several unit cell volume values ranging from 522.18 $\AA^{3}$ to $528.41 \AA^{3}$, respectively [40-41]. As it concerns the francolite phase, the values range from a minimum of $518.73 \AA^{3}$ to a maximum of $523.81 \AA^{3}$ [42-43]. These findings support previous observations $[44,3]$ who reports that fossilisation involves the transformation from bioapatite to francolite (i.e., authigenic bioapatite) by dissolution-reprecipitation mechanisms in long times of reaction. Typically, fluorapatite is preserved in fossil teeth and fossil bones: during the burial of bones and teeth (in some cases for millions of years), fluoride in the water-bearing soil and sediments substitutes into the original bone and tooth bioapatite [45-46].

Figure 1 display the a-vs c-axis best-fit values of the hexagonal space group, where we can observe clearly two well distinct and separated group of data.

The ancient, modern and burned bones occupy the rhs of the plot in force of their a-axis values higher than $9.42 \AA$, while the fossil bones are located in the lhs region because of the low a-axis values due to phenomena like fluorination and assumption of carbonate groups

The numerical value of the splitting factor SF in the $v_{4}$ band of phosphates supplies a direct method about the crystallinity of a sample in alternative to the XRD evaluation of the crystallite size extension from line broadening analysis of XRD samples. Table 2 reports the SF values related to ATR spectra performed on all the bone samples here examined. In agreement with the XRD analysis, the fossil and the burned bones have a higher crystallinity (and hence a greater SF) compared to modern bones, with very few exceptions.

Nevertheless it must be considered that this value can be strongly influenced by the presence of other mineral phases (especially if phosphates) and their \% over bioapatite, which can deform and shift the band $v_{4}$, making critical the SF calculation in some cases [47]. This calls for a careful observation of $v_{4}$ band, as well as integration of the results obtained from the XRD analysis to obtain the largest and accurate number of information about the sample [47]. 
Figure 2 shows four paradigmatic examples about the variability of $v_{4}$ band (the cluster of peaks in the range 550-650 $\mathrm{cm}^{-1}$ belong to the vibration modes of $\mathrm{PO}_{4}{ }^{3-}$ molecular groups), due to the type of sample and its composition [18].

The ATR-IR spectrum of TB3 fossil turtle shows the characteristic $v_{4}$ band of fluorapatite. Note that the peak at $563 \mathrm{~cm}^{-1}$ is, as customary, of intensity higher than that of the peak at $601 \mathrm{~cm}^{-1}$. Moreover, there is a slight shoulder at about $575 \mathrm{~cm}^{-1}$.

We can observe the same shoulder much more pronounced (at ca. $577 \mathrm{~cm}^{-1}$ ) in the Patiras dinosaur. We also note a slight shift of the two peaks (in this case, they occur at 566 and $604 \mathrm{~cm}^{-1}$ respectively), and especially the peaks show approximately the same height.

The ATR-IR spectrum of CCNII7-VI vertebra sample presents a SF value unusually high if referred to a modern bone sample ( $\mathrm{SF}=4.07)$, probably due to of the presence of brushite, which also affects the shape of the $v_{4}$ band, which presents a visible shoulder at $525 \mathrm{~cm}^{-1}$ indicated by the arrow. Also in this case we can observe a shift of the peaks, in particular of the first, which in this case is located at $559 \mathrm{~cm}^{-1}$. The more complex and interesting case concerning the $D-1100$ burned tooth sample. The spectrum show a new absorption band at \pm 630 which indicate that the sample has been heated over $700{ }^{\circ} \mathrm{C}$ [48], and the massive presence of $\beta$-TCP (45 wt.\%, see Table 2) has strongly deformed the $v_{4}$ band due to the overlap with the $v_{4}$ band of bioapatite (see the deformation of the peak at $554 \mathrm{~cm}^{-1}$ ), and also the SF calculation appears problematic. In fact, the numerical value $(\mathrm{SF}=3.13$ ) is very low if compared to other burned bone samples (see Table 2).

In the following we will restrict the discussion concerning the most peculiar cases together with the presentation of TEM images.

\section{a) modern bones}

In modern bioapatites, the XRD line broadening of the (001) peak narrower than the other profile indices may be taken as an indication of the anisotropic shape of the crystallites.

Figure 3a shows the XRD pattern of CCNI17-VI sample. The Rietveld fit is able to resolve the whole pattern with the main contribution from bioapatite (90 wt.\%) and the remaininig $10 \mathrm{wt} . \%$ consisting of brushite (dicalcium phosphate dihydrate), which is another Ca-phospate of chemical formula $\mathrm{CaHPO}_{4} \cdot\left(2 \mathrm{H}_{2} \mathrm{O}\right)$. This is the first time that we find this phase associated to a modern bone. It is possible to explain the presence of brushite by a presumed orthopedic surgery who suffered the CCNI17 individual during her life. In fact the treatment of bone defects (i.e. bone deficiency because of trauma, tumour or infections) represents a challenge for orthopaedic surgeons owing to lack of therapeutic approaches that are able to fully restore the lost bone, and brushite cements have 
raised in the last few years special interest because they are resorbed in vivo much faster than bioapatite ones due to their metastable nature in physiological fluids [49-50].

Only in another case concerning a dinosaur bone we had found brushite as a complete substitute of biopapatite [6].

The line broadening associated to the bioapatite peak profiles are ascribed, as usual to the limited extent of the average crystallite size, although in this case we have a value of $210 \AA$, slightly higher with respect to an expected value of 150-170 $\AA$ for modern bones [20-21]. This behavior is accounted for by the MAUD program with the Popa model [29]. Generally the model fit results suggest very small average crystallite size whose shape is elongated along the c-axis; in this case we can notice a slight elongation of a-axis as it is displayed in the Figure $3 \mathrm{~b}$. The lattice parameters assuming a hexagonal P63/m space group returns best-fit values for $\mathrm{a}=9.446$ and $\mathrm{c}=6.894 \AA$, respectively, indicative of Ca-deficient bioapatite.

As a matter of facts, after Rietveld fit of the CCNI18-VI and CCNII8-VII samples, lattice parameters a and c higher than 9.430 and $6.898 \AA$ respectively were returned by the numerical analysis. Again, this suggests the presence of Ca-deficient bioapatite (see Table 2). The observed increased volume of the unit cell implies a small increase of nearest neighbour distances at parity of fractional coordinates of atomic species. In turn, this would lead to a sort of weakening of the structure stability at high temperature, thus favouring the transformation of bioapatite to $\beta$-TCP (whitlockite structure), as it may occur with a different, lower transformation temperature.

However, as it was suggested by Wilson et al. [51] imperfect modeling of the structure in the refinement, particularly the disorder associated with the second $\mathrm{Ca}$ site, resulted in errors in $\mathrm{Ca}_{2}$ occupancies, making doubtful this association. Concerning the determination of lattice disorder by XRD, the numerical value that can be obtained after the Rietveld method may be affected by two concomitant factors. The first is ascribed to the difficult of measuring precisely the broadening of peaks with high- $h k l$ orders which are of weak intensity because of the scattering factor of elements. Additionally, the reciprocal space involved using CuKa limits further higher $h k l$ terms desired for the analysis. The morphology of particles observed by TEM (see Figure 4) was identified as irregular nanometric platelet crystals within mineralized collagen fibrils (Figure 4 a,b,c). In some cases can be observed distinct plate-like and tablet-like bioapatite crystals (Figure 4d). Plate-like crystals have often irregular edges, with no well defined profile and were rather low in density. Tablet-like crystals, however, had distinct boundaries, with a well-defined, oblong profile and were much denser than plate-like crystals (Figure 4 e,f). In CCNI18-VII and CCNI17-VI samples

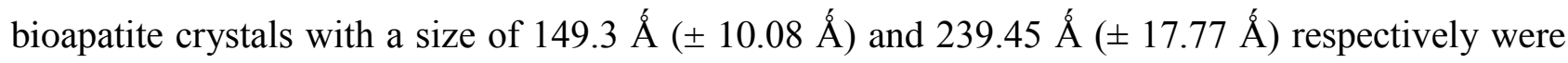
measured. 


\section{b) fossil/ancient bones}

The XRD pattern from the IPS-35594 paleontological sample, which is the oldest in our collection (Permo-Triassic, ca. $245 \mathrm{Ma}$ ), is reported in Figure 5a. The bioapatite component (actually a fluorapatite as it is suggested by the value of the a-axis parameter $=9.371 \AA$ ) amounts to only 53 wt.\% of the entire specimen, which is affected by the strong presence of calcite (21 wt.\%), merlinoite (10 wt.\%), dolomite (10 wt.\%) and quartz (6 wt.\%) phases. Moreover, the average crystallite size of fluorapatite is $671 \AA$, on account of growth phenomena induced by severe fossilization process. Also note the average shape for such crystallites, that turn out to be elongated along the c-axis as well as the a- and b-axes (Figure 5b) displaying a kind of "potato-like" shape. The XRD pattern of ancient UF-755 tumoral bone (Figure 6a) follow the trend already revealed for the modern bones both of humans and animals that were reported in our previous work [21]. The experiment (data points) was fit satisfactorily with the full line after including structure information from the mineral bioapatite (99.0 wt.\%), and quartz (1.0 wt.\%), probably of exogenous origin. After assuming an hexagonal P63/m space group, the Rietveld program returns $\mathrm{a}=9.431$ and $\mathrm{c}=$ $6.899 \AA$ best-fit values, respectively. The average shape of crystallites turn out to be elongated along the c-axis (Figure 6b); this model differs slightly from that shown in Figure $3 b$, may be because of the lower average crystallite size (170 ̊́) involved in the tumoral bone.

According to TEM images (see Figure 7) the crystal features of archaeological and palaeontological bone specimens were different from those observed in the modern references. The bioapatite mineral is highly divided and very poorly organized, because of the complete loss of organic material. We can observe well separated single crystals, with a well-defined polygonal or elongated rectangular shape (Figure 7 a,b,c,d). The tumor show dense groupings of extremely thin plateletlike crystals, and there is no trace of collagen longitudinally-sectioned fibrils (Figure 7e). Crystallographic bioapatite planes can also be distinguished by resolution of lattice fringes in some single crystals. These fringes show the regularity of the crystals and permit the exact determination of the coherent crystal domains. We measured the average size of the bioapatite crystals in Patiras

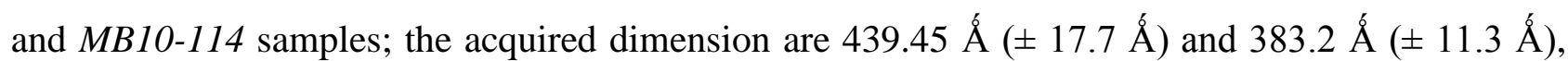
which are in agreement with XRD values obtained from the MAUD program (see Table 2). The distances between visible fringes in MB10-114 dinosaur teeth (Figure 7f) were ca 6.65 and 5.60 $\AA$, which corresponds to the $(001)$ and $(211,121)$ planes of bioapatite.

\section{c) burned bones}


The diffraction data of burned $D-1100$ tooth is reported in Figure 8a. The pattern show narrow peaks and the phase analysis suggest that the material is a mixture of bioapatite and $\beta$-Three Calcium Phosphate $\mathrm{Ca}_{3}\left(\mathrm{PO}_{4}\right)_{2}$ (whitlockite structure). Likely this is the high-temperature decomposition product of bioapatite following the chemical reaction:

\section{$2 \mathrm{Ca} 5\left(\mathrm{PO}_{4}\right)_{3} \mathrm{OH} \rightarrow 3 \mathrm{Ca}_{3}\left(\mathrm{PO}_{4}\right)_{2}(\beta-\mathrm{TCP})+\mathrm{CaO}+\mathrm{H}_{2} \mathrm{O}$}

The lattice parameter of the $\beta$-TCP phase (44 wt\%), space group R3c, in the hexagonal settings are: $\mathrm{a}=10.383$ and $\mathrm{c}=37.221 \AA$, respectively. Weak peaks are also observed in the final pattern due to a small contribution of $\mathrm{MgO}$ phase as a consequence of possible impurities in the bone material. Some anisotropy is still present since the average crystallite size depicted by the anisotropic model has a nearly spherical shape (as shown in the figure $8 b$ ).

The TEM images of burned bones show larger and well separated single crystals with a hexagonal morphology (often with irregular edges), as shown in Figure 9 (a,b,c,d,e). In C5T9, CCNI18-VII

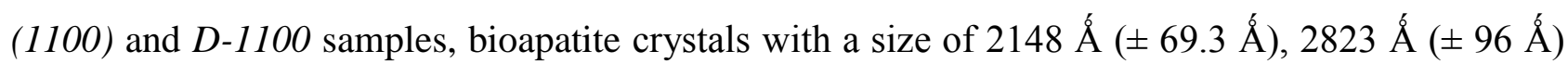
and $1620 \AA \AA$ ( $(433 \AA$ Á) respectively were measured. The distance between visible fringes in $D-1100$ sample (figure 9f) was about $7.98 \AA$, which corresponds to the (012) planes of whitlockite.

\section{CONCLUSIONS}

We have addressed an XRD study, supported by ATR-IR and Transmission electron micrograph (TEM) images on a collection of sixteen bone specimens referred to an age time range from $240 \mathrm{Ma}$ to modern times to investigate changes of apatite due to fossilization or burning processes in terms of physico-chemical properties related with the structure.

The study allow to confirm various points that have been enlighted in previous investigations.

The crystallinity appears to increase as a function of diagenetic processes and/or heat treatment. Moreover, the mineralogical composition varies according to the sediment, and presents a greater complexity in the oldest paleontological samples, in which numerous phases enter into the bone structure and may considerably reduce the amount of apatite. An additional contribution to the above well-established conclusions is supplied by TEM images, which are revealing the organization of modern bones within mineralized collagen fibrils, where we can observe distinct plate-like and tablet-like apatite crystals of small dimensions, in accordance with XRD analysis from the reciprocal space. Fossil and burned bones have larger crystals, with hexagonal or polygonal well- defined size and often with irregular edges, with no apparent organization because 
of complete loss of organic material. Further experiments should be addressed to burnt fossil samples, in order to verify/reject the occurrence of such distinct features.

\section{Acknowledgments}

The authors thank Dr. Àngel Galobart (Institut Català de Paleontologia, Sabadell-Barcelona, Spain) for supplying the fossil osseous materials employed in this study. The authors also thank the Serveis de Microscopia, Dr. Eva Pellicer and Elisa Tolu (Universitat Autonoma de Barcelona) for their technical assistance.

This work is supported by Autonomous Region of Sardinia (LR3/2008-R.Cervelli, S.Politiche), with the research project titled: "Archaeometric and physico-chemical investigation using a multitechnique approach on archaeological, anthropological and paleontological materials from the Mediterranean area and Sardinia".

\section{REFERENCES}

1) E.T. Stathopoulou, V. Psycharis, G.D. Chryssikos. Palaeogeogr. Palaeoclimatol. Palaeoecol. 266, 168-174 (2008).

2) G. Piga, A. Santos-Cubedo, S. Moya Solà, A. Brunetti, A. Malgosa, S. Enzo, J. Archaeol. Sci. 36 (9), 1857-1868 (2009).

3) G. Piga, A. Santos-Cubedo, A. Brunetti, M. Piccinini, A. Malgosa, E. Napolitano, S. Enzo, Palaeogeogr. Palaeoclimatol. Palaeoecol. 310 (1-2), 92-107 (2011).

4) G. Piga, M. Guirguis, P. Bartoloni, A. Malgosa, S. Enzo. Int. J. Osteoarchaeol. 20, 144-157 (2010).

5) G. Piga, J.H. Hernández-Gasch, A. Malgosa, M.L. Ganadu, S. Enzo. Homo 61, 440-452 (2010).

6) G. Piga, A. Brunetti, B. Lasio, L. Malfatti, À. Galobart, F.M. Dalla Vecchia, S. Enzo. Appl. Phys. A. 118, 487-496 (2015).

7) G. Piga, J. Marmi, A. Galobart, A. Brunetti, B. Lasio, L. Malfatti, S. Enzo. Spectrochim. Acta B 119, 50-64 (2016).

8) S. Weiner, W. Traub. Faseb J. 6, 879-885 (1992).

9) J.-Y. Rho, L. Kuhn-Spearing, P. Ziuopos. Med. Eng. Phys. 20, 92-102 (1998).

10) S. Weiner, H.D.Wagner. Annu. Rev. Mater. Sci. 28, 271-298 (1998).

11) J.D. Currey. Princeton University Press, Princeton, NJ (2002). 
12) X.Y. Wang, Y. Zuo, D. Huang, X.-D. Hou, Y.-B. Li. Biomed. Environ. Sci. 23, 473-480 (2010).

13) S. Weiner, P.A. Price. Calcified Tissue Int. 39, 365-375 (1986).

14) H.D. Wagner, S. Weiner. J. Biomech. 25, 1311-1320 (1992).

15) M. D’Elia, G. Gianfrate, G. Quarta, L. Giotta, G. Giancane, L. Calcagnile. Radiocarbon 49, 201-210 (2007).

16) S.E. Etok, E. Valsami-Jones, T.J. Wess, J.C. Hiller, C.A. Maxwell, K.D. Rogers, D.A.C. Manning, M.L. White, E. Lopez-Capel, M.J. Collins, M. Buckley, K.E.H. Penkman, S.L. Woodgate. J. Mater. Sci. 42, 9807-9816 (2007).

17) L.D. Mkukuma, J.M.S. Skakle, I.R. Gibson, C.T. Imrie, R.M. Aspden, D.W.L. Hukins. Calcified Tissue Int. 75, 321-328 (2004).

18) L. Berzina-Cimdina, N. Borodajenko. Materials Science, Engineering and Technology, Prof. Theophanides Theophile (Ed.), ISBN: 978-953-51-0537-4, InTech, Available from:http://www.intechopen.com/books/infrared-spectroscopy-materials-scienceengineering-and-technology/research-of-calcium-phosphates-using-fourier-transformationinfrared-spectroscopy (2012).

19) J.C. Elliott, R.M. Wilson and S.E.P. Dowker, advances in X-ray analysis 45, 172-181 (2002).

20) G. Piga, T.J.U. Thompson, A. Malgosa, S. Enzo. J. Forensic. Sci. 54, 534-539 (2009).

21) G. Piga, G. Solinas, T.J.U. Thompson, A. Brunetti, A. Malgosa, S. Enzo. J. Archaeol. Sci. 40, 778-785 (2013).

22) E.M. Boatman, R. Gronsky, M.B. Goodwin, R.O. Ritchie. Micros. Today 21 (5), 34-40 2013.

23) I. Reiche, C. Vignaud, M. Menu. Solid State Sci. 2 625-636 (2000).

24) I. Reiche, C. Vignaud, M. Menu. Archaeometry 44 (3), 447-459 (2002).

25) M.T. Ferreira, R. Vicente, D. Navega, D. Gonçalves, F. Curate, E. Cunha. Forensic Sci. Int. 245, 202.e1-202.e5 (2014).

26) H.M. Rietveld. Acta Crystallogr. 22, 151-152 (1967).

27) L. Lutterotti. Nuclear Inst. and Methods in Physics Research B 268, 334-340 (2010).

28) S. Grazulis, D. Chateigner, R.T. Downs, A.F.T. Yokochi, M. Quiro, L. Lutterotti, E. Manakova, J. Butkus, P. Moeck, A. Le Bail. J.Appl.Cryst. 42, 726-729 (2009).

29) N.C. Popa. J. Appl. Crystallogr. 31, 176-180 (1998).

30) S. Weiner, O. Bar Yosef. J. Archaeol. Sci. 17, 187-196 (1990).

31) Weiner, S., Goldberg, P., Bar Yosef, O. J. Archaeol. Sci. 20, 613-628 (1993). 
32) R.E.M. Hedges, A.R. Millard, A.W.G. Pike. J. Archaeol. Sci. 22, 201-209 (1995).

33) A. Sillen, J. Parkington. J. Archaeol. Sci. 23, 535-542 (1996).

34) V. Michel, P. Ildefonse, G. Morin. 1996. Palaeogeogr. Palaeogeogr. Palaeoclimatol. Palaeoecol. 126, 109-119 (1996).

35) Wright, L.E., Schwarcz, H.P. J. Archaeol. Sci. 23, 933-944 (1996).

36) K.E. Squires, T.J.U. Thompson, M. Islam, A. Chamberlain. J. Archaeol. Sci. 38, 2399-2409 (2011).

37) G. Piga, A. Malgosa, T.J.U. Thompson, M. Guirguis, S. Enzo. Int. J. Osteoarchaeol. 25, 146-159 (2015).

38) G. Piga, M. Guirguis, T.J.U. Thompson, A. Isidro, S. Enzo, A. Malgosa. Homo 61, 50-64 (2016).

39) G. Ma, X.Y. Liu. Cryst. Growth Des. 9, 2991-2994 (2009).

40) K. Sudarsanan, P.E. Mackie, R.A. Young. Mat. Res. Bull. 7, 1331-1338 (1972).

41) K. Sudarsanan, R.A. Young. Acta Cryst. B. 34, 1401-1407 (1978).

42) J. Elorza, H. Astibia, X. Murelaga, X. Pereda-Suberbiola. Cretaceous Research 20, 169-187 (1999).

43) B. Perdikatsis. Mat. Sci. Forum 79: 809-814 (1991).

44) Y. Kolodny, B. Luz, M. Sander, W.A. Clemens. Palaeogeogr. Palaeoclimatol. Palaeoecol. 126, 161-171 (1996).

45) M.J. Kohn, T.E. Cerling. in: M.J. Kohn, J. Rakovan, J.M. Hughes (Eds.), Phosphates: Geochemical, Geobiological and Material Importance, Reviews in Mineralogy and Geochemistry 48, Mineralogical Society of America, Washington, DC, 455-488 (2002).

46) S.K. Dwivedi, S. Dey, D. Swarup, Sci. Total Environ. 207 105-109 (1997).

47) G. Piga, D. Gonçalves, T.J.U. Thompson, A. Brunetti, A. Malgosa, S. Enzo. Int. J. Spectrosc. Article ID 4810149 (doi: 10.1155/2016/4810149) (2016).

48) G. Monge, M.I. Carretero, M. Pozo, C. Barroso. J. Archaeol. Sci. 46, 6-15 (2014).

49) S. Pina, J.M.F. Ferreira. Materials 3, 519-535 (2010).

50) G. Cama, B. Gharibi, J. C. Knowles, S. Romeed, L. DiSilvio, S. Deb. J. R. Soc. Interface 11, 20140727.

51) R.M. Wilson, J.C. Elliott, S.E.P. Dowker, L.M. Rodriguez-Lorenzo. Biomaterials 26, $1317-$ 1327 (2005). 


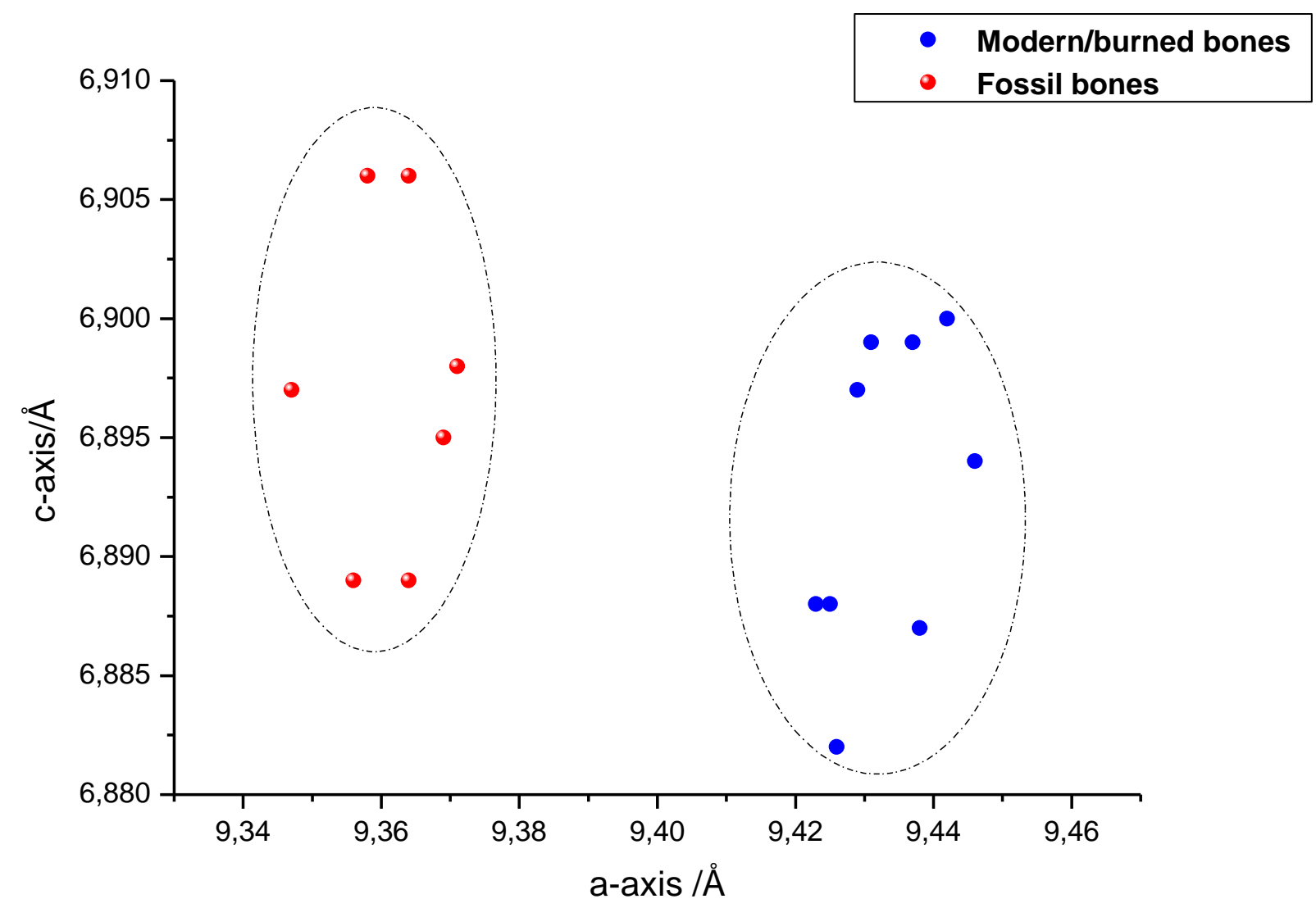

Figure 1: a vs c-axis values of the bioapatites analyzed. Two distinct groups are clearly ascribable to fluorapatite or francolite (red symbols) and modern or burned bioapatites (blue symbols). 


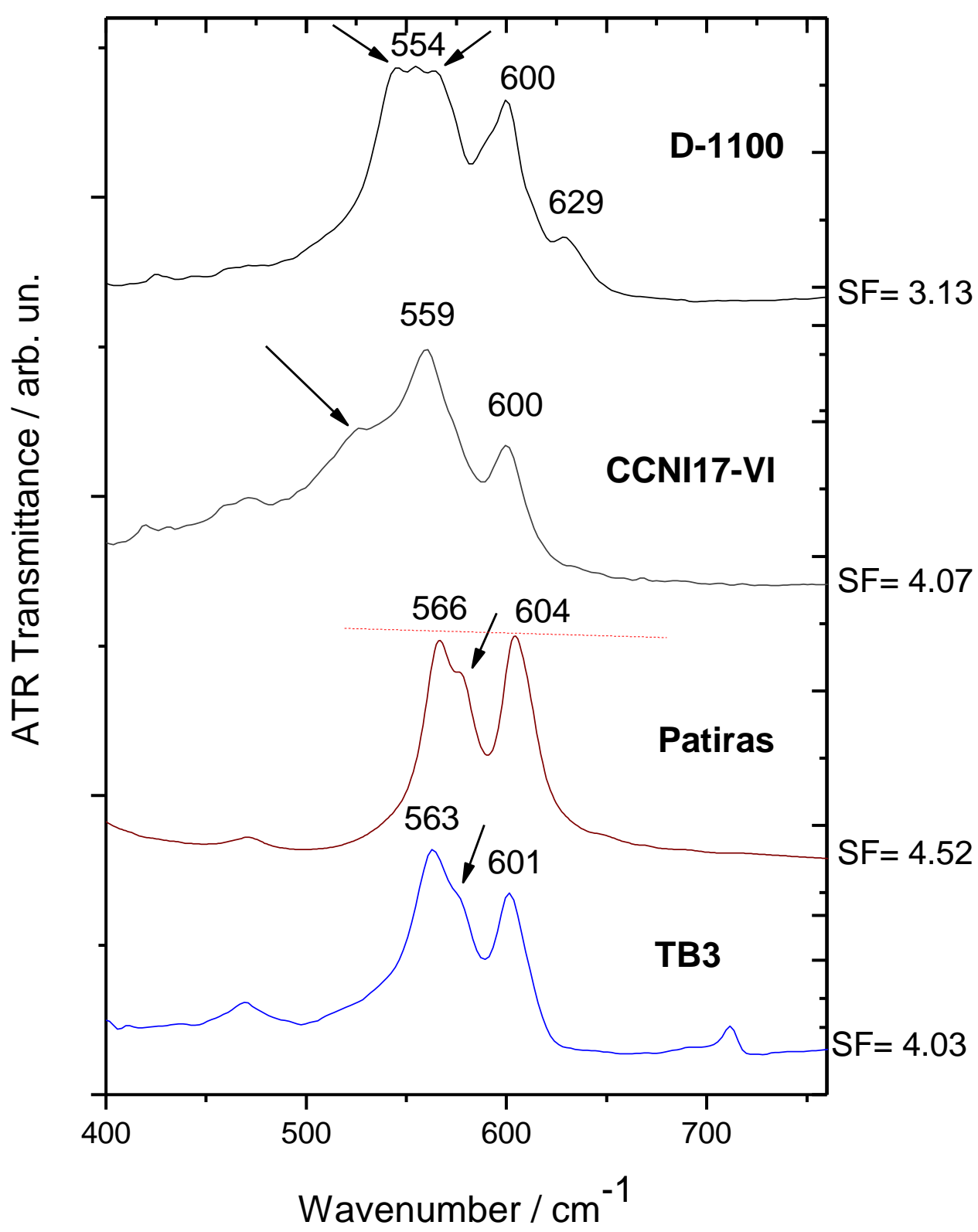

Figure 2: magnification of $v_{4}\left(\mathrm{PO}_{4}\right)$ bands of four representative samples (from bottom to top: TB3 fossil turtle, Patiras dinosaur, CCNI17-VI modern human vertebra and D-1100 burned tooth) in the frequency range where the SF splitting factor are worked out numerically and their figures reported. We can note a complex deformation of the $v_{4}$ band, together with the shift of peaks according to their different composition. 


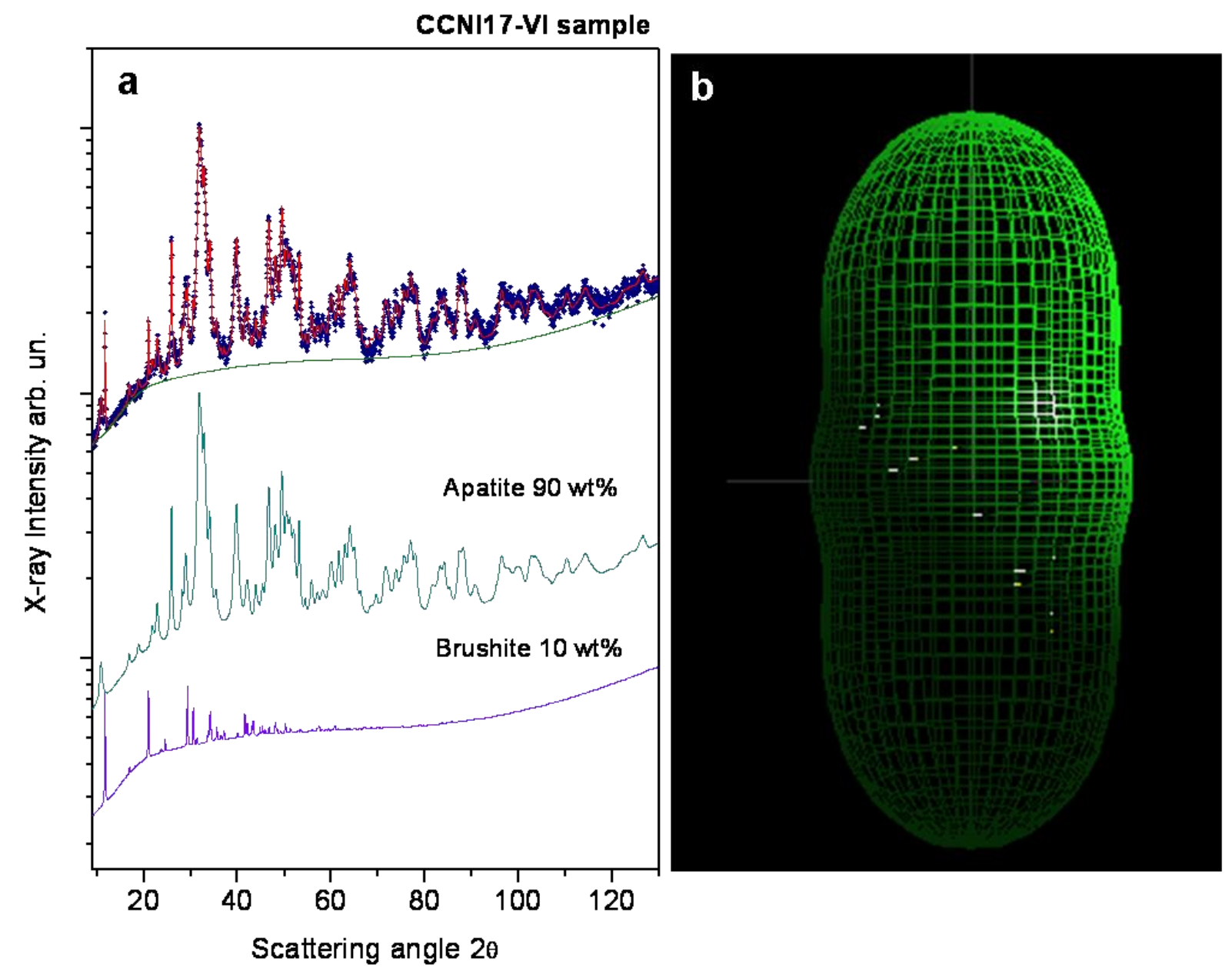

Figure 3: a) the pattern of CCNI17-VI human vertebra has detected the presence of dicalcium phosphate dihydrate (brushite) (10 wt.\%), indication of a probable orthopedic surgery. b) the average crystallite shape is elongated along the c-axis; in this case we can notice also a slight elongation of a-axis. 

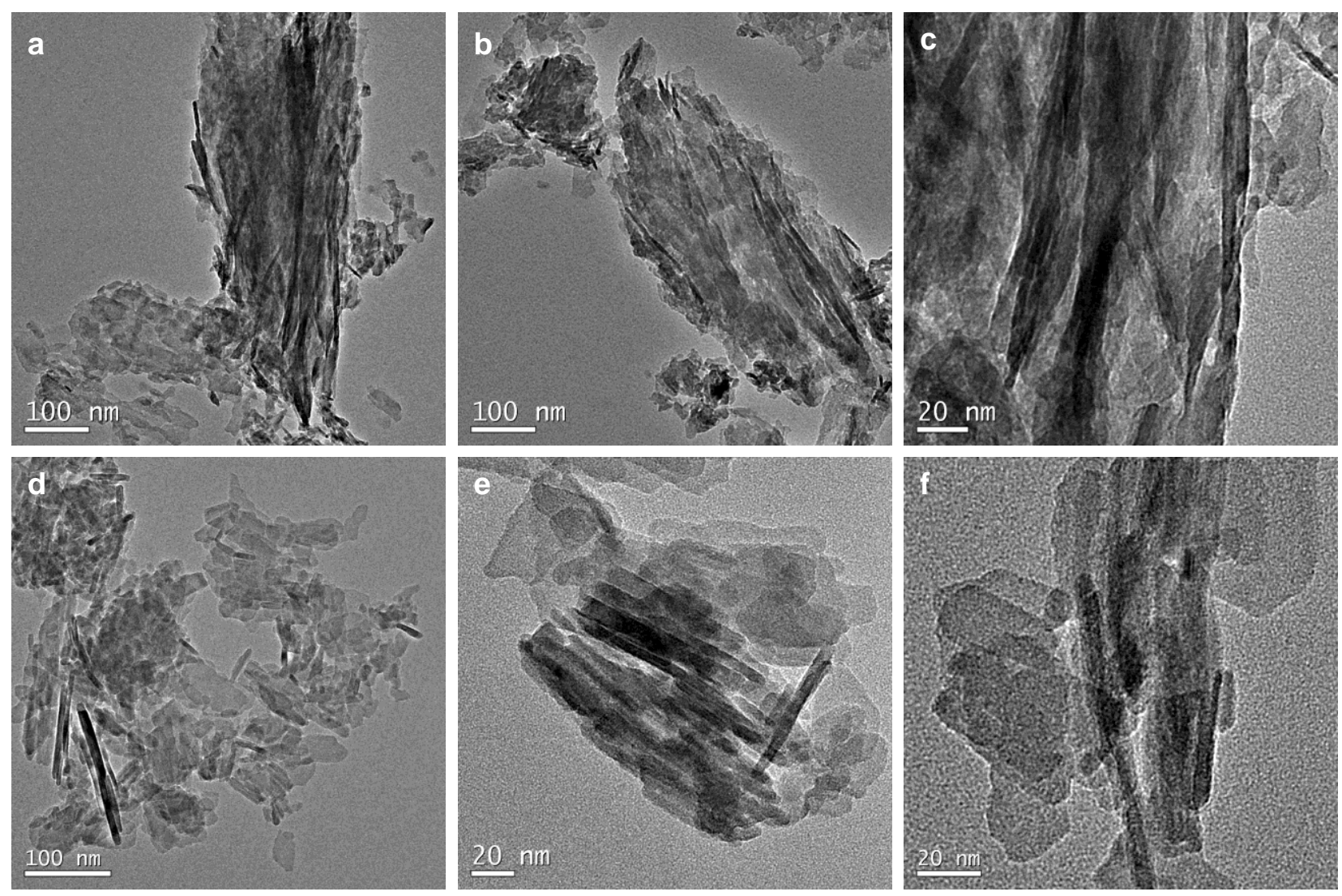

Figure 4: TEM images of the hydroxylapatite particles extracted from modern human bone samples. 


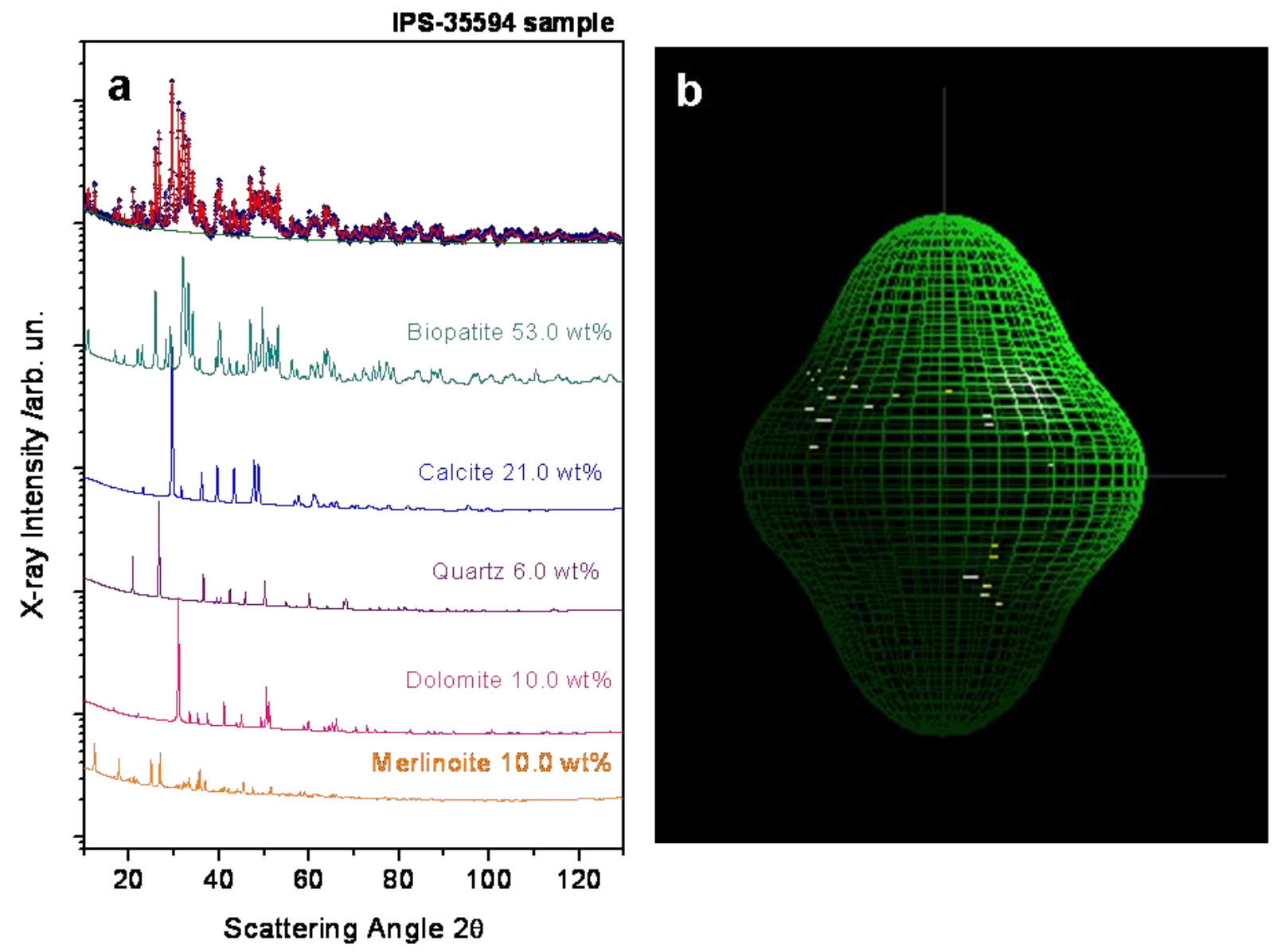

Figure 5: a) the XRD pattern of IPS 35594 Seimuromorpha specimen (Middle Triassic, $245 \mathrm{Ma}$ ) highlights a complex five phase constitution. b) The approximate, average crystallite shape from Popa model turn out to be elongated along the c-axis as well as the a- and b-axes. 


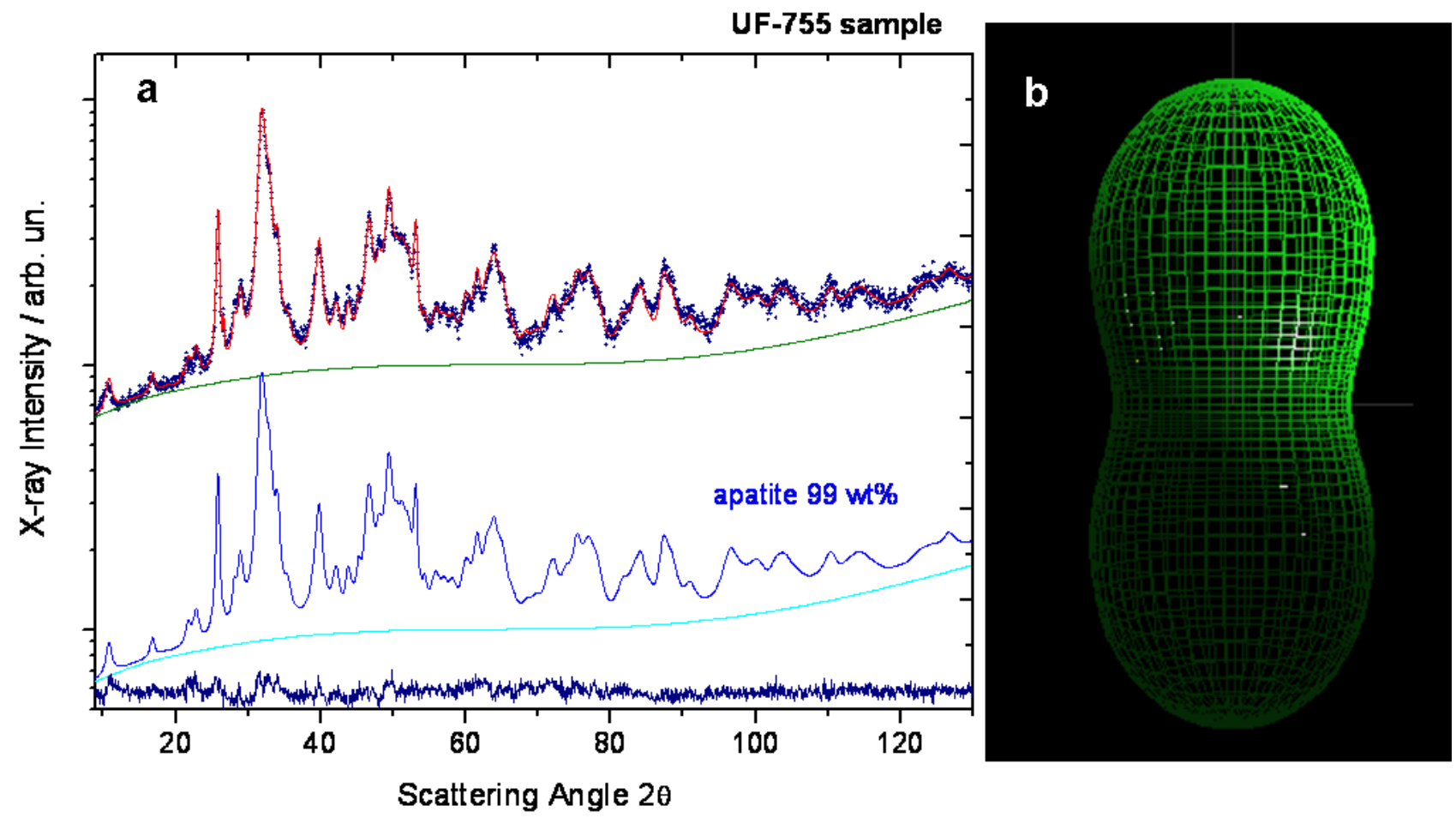

Figure 6: a) The XRD pattern of tumoral bone (enchondroma) follows the trend of a normal human or animal bone and is composed by $99 \mathrm{wt} . \%$ of apatite and a small quartz contribution (1 wt. $\%)$ likely of exogenous origin. b) The average shape turn out to be elongated along the c-axis. 

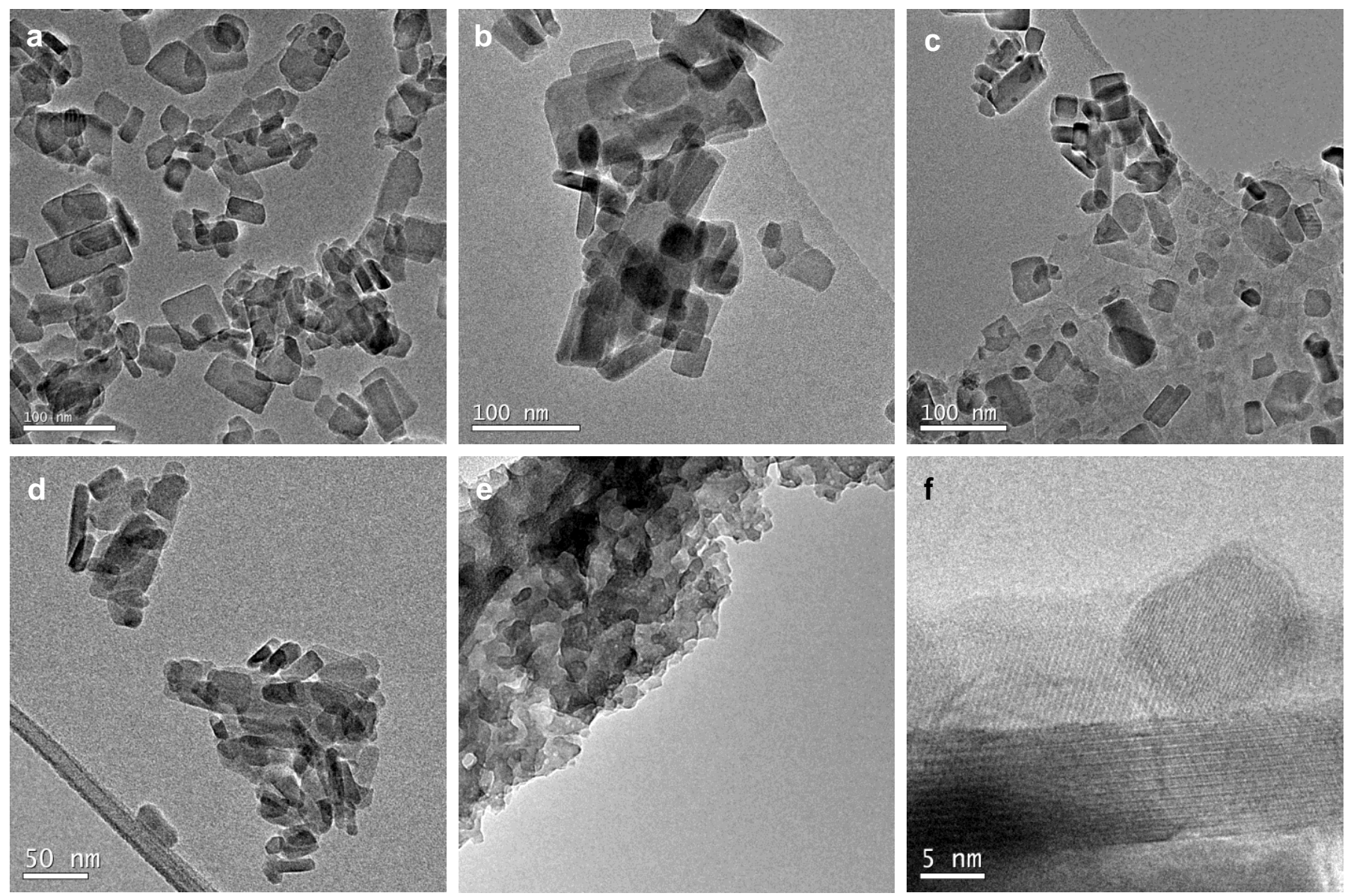

Figure 7: TEM images of fossil and ancient bones where we can observe well-defined polygonal or elongated rectangular shape of crystals. In detail: a) Patiras b) IPS-37438 c) IPS-35594 d) MB10114 e) UF-755 tumoral bone f) atoms fringes in MB10-114 dinosaur teeth. 


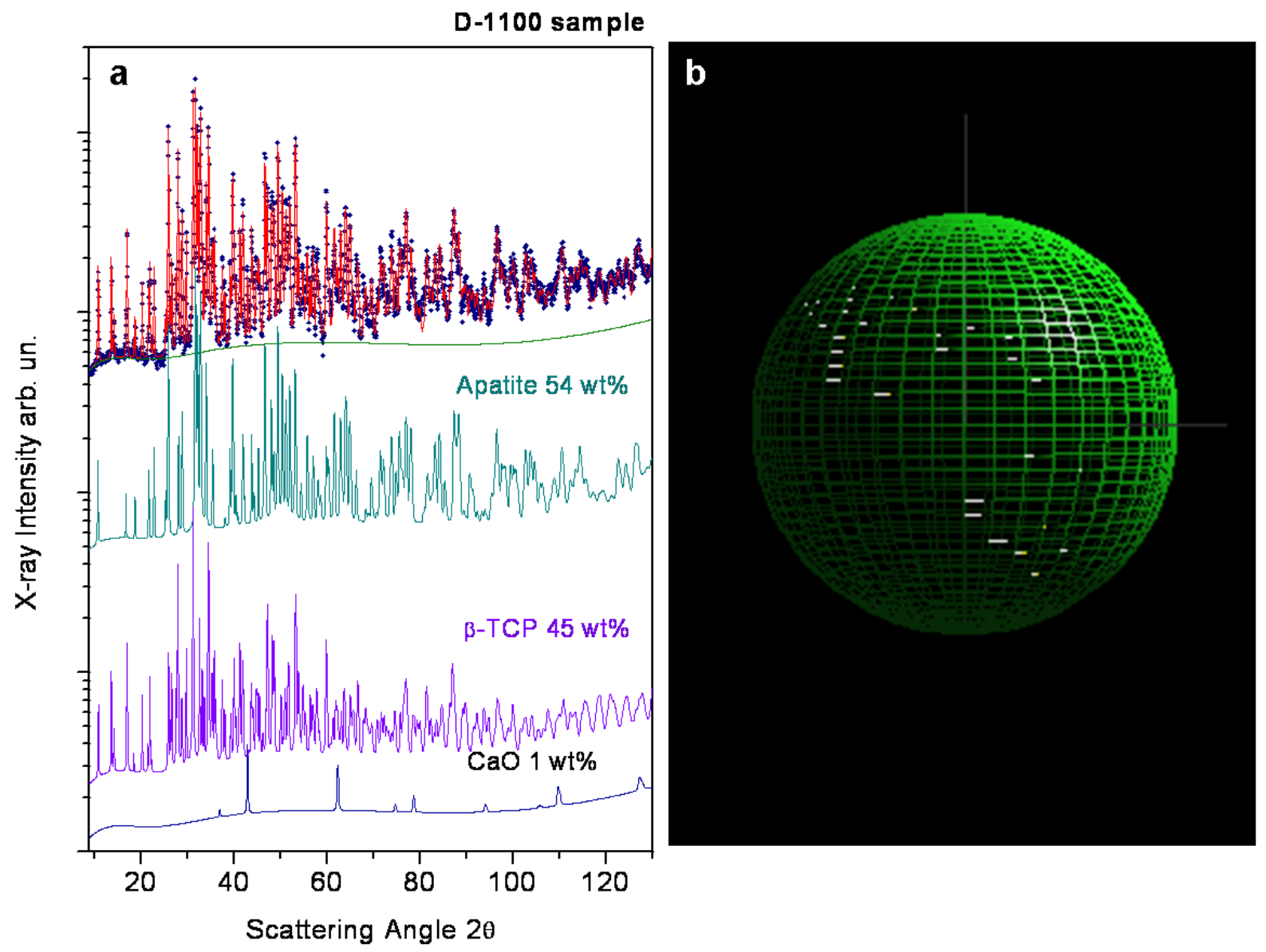

Figure 8: a) the XRD pattern of D-1100 burned human tooth shows a partial transformation to $\beta$ Three Calcium Phosphate (whitlockite structure). The amount of bioapatite is $54 \mathrm{wt} \%$. b) the Popa anisotropic model has a nearly spherical shape. 

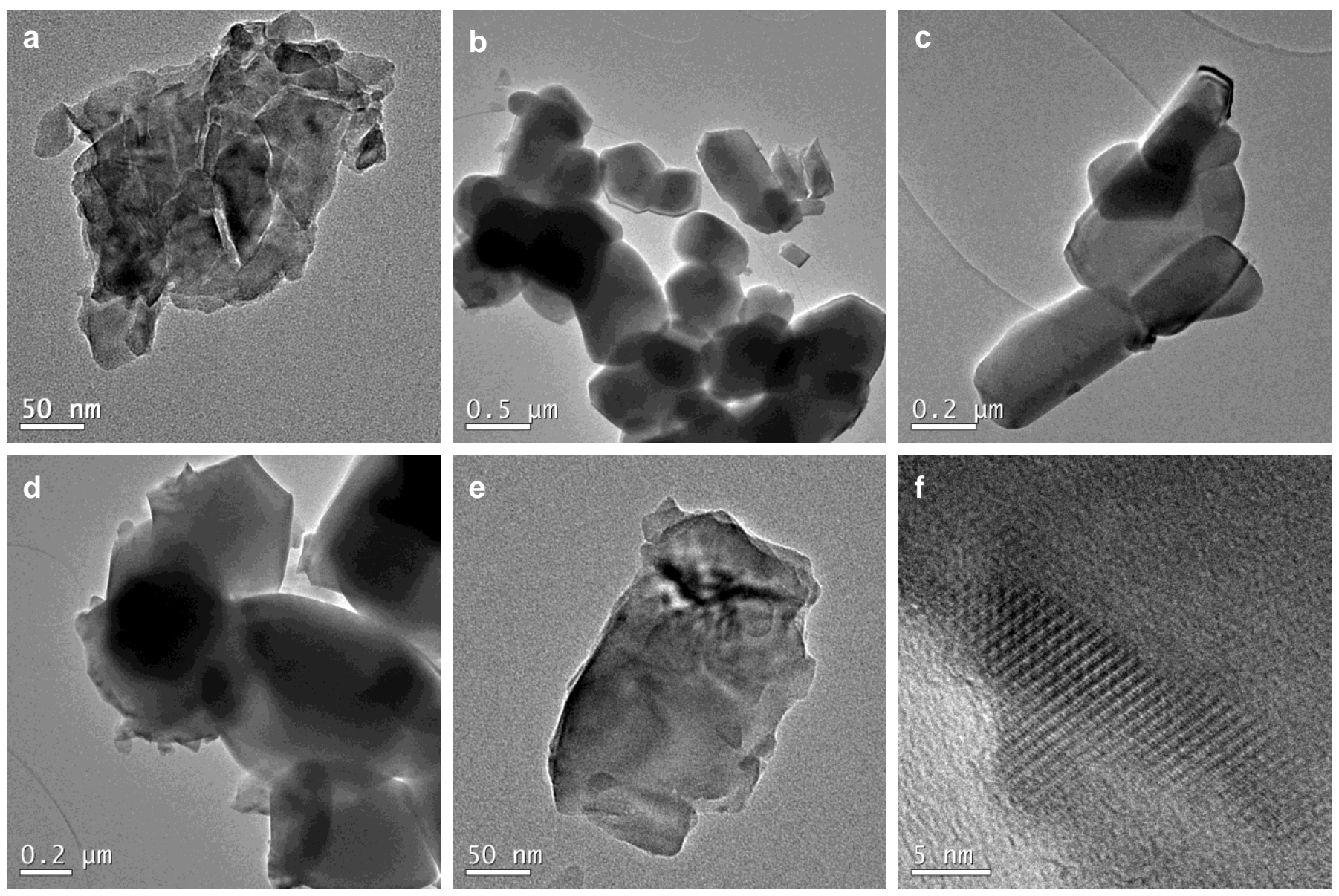

Figure 9: TEM images of burned bones show large crystals, with hexagonal morphology, often with irregular edges. In detail: a) $T 252$ b) C5T9 c) CCNI18-VII (1100) d, e) D-1100 f) atoms fringes in $D-1100$ burned human teeth. 


\begin{tabular}{|c|c|c|}
\hline SAMPLE CODE & CHRONOLOGY & CLASSIFICATION \\
\hline IPS-35594 & Middle Triassic (Anisian) (245 Ma) & Seimuromorpha \\
\hline Patiras & $\begin{array}{c}\text { Lower Cretaceous (Aptian) } \\
(125-112 \mathrm{Ma})\end{array}$ & Undetermined Dinosaur \\
\hline MB10-114 & Upper Cretaceous (75-65 Ma) & $\begin{array}{l}\text { Crocodyliform (ziphodont) } \\
\text { (tooth) }\end{array}$ \\
\hline TB-3 & Upper Cretaceous (75-65 Ma) & Turtle plate \\
\hline Orcau-1 & Upper Cretaceous (75-65 Ma) & Dinosaur (Hadrosauria) \\
\hline Espinau & Upper Cretaceous (75-65 Ma) & Dinosaur (Hadrosauria) \\
\hline IPS-37438 & Eocene (Priabonian) (33.9-37.2 Ma) & Undetermined Reptile \\
\hline UF -755 & Carolingian (VIII ${ }^{\text {th }}-\mathrm{X}$ century BC) & Human benign cartilaginous tumor \\
\hline T252 & $\left(\mathrm{VII}^{\text {th }}-\mathrm{VI}^{\text {th }}\right.$ century BC) & Burned human ulna \\
\hline C5T9 & $\left(\mathrm{V}^{\text {th }}-\mathrm{III}^{\mathrm{rd}}\right.$ century BC) & Burned human cranium \\
\hline CCNI18-VII (1100) & Modern times & Burned human vertebra \\
\hline D-1100 & Modern times & Burned human tooth \\
\hline CCNI17-VI & Modern times & Human vertebra \\
\hline CCNI18-VI & Modern times & Human vertebra \\
\hline CCNI18-VII & Modern times & Human vertebra \\
\hline CEIXXI160 & Modern times & Human Right humerus proximal \\
\hline
\end{tabular}

Table 1: list of the 16 bone specimens used in this study with chronology and classification.

\begin{tabular}{|c|c|c|c|c|c|c|c|}
\hline Sample code & $\begin{array}{c}\text { Crystallographic phases } \\
\text { (wt \%) }\end{array}$ & $\begin{array}{l}\mathbf{R}_{\mathbf{w p}} \\
(\boldsymbol{\%})\end{array}$ & $\begin{array}{l}\text { a-axis } \\
/ \AA\end{array}$ & $\begin{array}{c}\text { c-axis } \\
/ \AA\end{array}$ & $\begin{array}{l}\text { Vcc } \\
/ \AA^{3}\end{array}$ & $\begin{array}{l}\langle\mathrm{D}> \\
/ \AA\end{array}$ & $\begin{array}{l}\text { SF- } \\
\text { ATR }\end{array}$ \\
\hline IPS-35594 & $\begin{array}{c}\text { Apatite } 53 \\
\text { Calcite } 21 \\
\text { Merlinoite } 10 \\
\text { Dolomite } 10 \\
\text { Quartz } 6 \\
\end{array}$ & 5.37 & 9.371 & 6.898 & 524.6 & 671 & 5.16 \\
\hline Patiras & Apatite 100 & 9.44 & 9.347 & 6.897 & 521.8 & 405 & 4.52 \\
\hline MB10-114 & $\begin{array}{l}\text { Apatite } 97 \\
\text { Calcite } 2 \\
\text { Quartz 1 }\end{array}$ & 5.4 & 9.369 & 6.895 & 524.1 & 310 & 4.41 \\
\hline TB-3 & $\begin{array}{c}\text { Apatite } 62 \\
\text { Calcite } 36 \\
\text { Barite } 2\end{array}$ & 7.5 & 9.356 & 6.889 & 522.2 & 325 & 4.03 \\
\hline Orcau-1 & $\begin{array}{c}\text { Apatite } 66 \\
\text { Calcite } 27 \\
\text { Quartz } 4 \\
\text { Merlinoite 3 }\end{array}$ & 4.1 & 9.364 & 6.889 & 523.1 & 510 & 4.36 \\
\hline Espinau & $\begin{array}{c}\text { Apatite } 70 \\
\text { Calcite } 23 \\
\text { Quartz } 7 \\
\end{array}$ & 5.8 & 9.364 & 6.906 & 524.4 & 300 & 3.80 \\
\hline IPS-37438 & $\begin{array}{c}\text { Apatite } 51 \\
\text { Calcite } 25 \\
\text { Merlinoite } 16 \\
\end{array}$ & 9.6 & 9.358 & 6.906 & 523.7 & 560 & 4.20 \\
\hline
\end{tabular}




\begin{tabular}{|c|c|c|c|c|c|c|c|}
\hline & Quartz 8 & & & & & & \\
\hline UF-755 & $\begin{array}{c}\text { Apatite 99 } \\
\text { Quartz 1 }\end{array}$ & 4.77 & 9.431 & 6.899 & 531.4 & 170 & 3.46 \\
\hline T252 & $\begin{array}{c}\text { Apatite 95 } \\
\text { Muscovite 5 }\end{array}$ & 7.28 & 9.423 & 6.888 & 529.7 & 2347 & 5.20 \\
\hline C5T9 & $\begin{array}{c}\text { Apatite 98 } \\
\text { Calcite 2 }\end{array}$ & 8.5 & 9.426 & 6.882 & 529.5 & 1900 & 5.44 \\
\hline CCNI18-VII (1100) & Apatite 100 & 8.88 & 9.425 & 6.888 & 529.9 & 2800 & 5.97 \\
\hline D-1100 & $\begin{array}{c}\text { Apatite 54 } \\
\text { B-TCP 45 } \\
\text { MgO 1 }\end{array}$ & 10.45 & 9.438 & 6.887 & 531.3 & 1940 & 3.13 \\
\hline CCNI17-VI & $\begin{array}{c}\text { Apatite 90 } \\
\text { Brushite 10 }\end{array}$ & 4.5 & 9.446 & 6.894 & 531.7 & 210 & 4.07 \\
\hline CCNI18-VI & Apatite 100 & 4.62 & 9.437 & 6.899 & 532.1 & 155 & 3.55 \\
\hline CCNI18-VII & Apatite 100 & 4.5 & 9.442 & 6.900 & 532.7 & 165 & 3.36 \\
\hline CEIXXI160 & Apatite 100 & 3.8 & 9.429 & 6.897 & 531.0 & 150 & 3.30 \\
\hline
\end{tabular}

Table 2: Phase crystallographic analysis obtained after Rieveld fit for the bone specimens here discussed. In the case of multiple phases, their relative wt $\%$ is reported in the second column. The third column displays the agreement factor between calculated and experimental data points of each XRD pattern at the end of the fit. a-axis and c-axis values (fourth and fifth column respectively) refer to the lattice parameters of hexagonal bioapatite, used as a proxy for the natural bone structure. The unit cell volume $\mathrm{a}^{2} \cdot \mathrm{c} \cdot \sin \left(60^{\circ}\right)$ is reported in the sixth column. The average size extension of crystallites from the line broadening analysis incorporated in the Rietveld program is given in the seventh column. Finally, the last column display the splitting factor (SF) values obtained from analysis of the ATR-IR $v_{4}$ band of phosphate groups according to Weiner and Bar-Yosef, 1990 [32]. 